\title{
NOVEMBER 1973
}

THIRTEENTH YEAR - No. 152

\section{international review of the red cross}

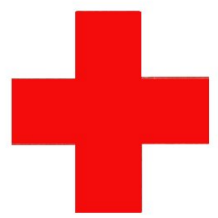

INTER ARMA CARITAS

GENEVA

INTERNATIONAL COMMITTEE OF THE RED CROSS FOUNDED IN 1863 


\section{INTERNATIONAL COMMITTEE OF THE RED CROSS}

Mr. ERIC MARTIN, Doctor of Medicine, Honorary Professor of the University of Geneva, President (member since 1973)

Mr. JEAN PICTET, Doctor of Laws, Chairman of the Legal Commission, Vice-President (1967)

Mr. HARALD HUBER, Doctor of Laws, Federal Court Judge, Vice-President (1969)

Mr. HANS BACHMANN, Doctor of Laws, Director of Finance of Winterthur (1958)

Mr. DIETRICH SCHINDLER, Doctor of Laws, Professor at the University of Zurich (1961)

Miss MARJORIE DUVILLARD, Nurse, former director of the Bon Secours Nursing School, Geneva (1961)

Mr. MAX PETITPIERRE, Doctor of Laws, former Swiss Federal Councillor (1961)

Mr. ADOLPHE GRAEDEL, former member of the Swiss National Council, former Secretary-General of the International Metal Workers Federation (1965)

Mrs. DENISE BINDSCHEDLER-ROBERT, Doctor of Laws, Professor at the Graduate Institute of International Studies, Geneva (1967)

Mr. MARCEL A. NAVILLE, Master of Arts, ICRC President from 1969 to 1973 (1967)

Mr. JACQUES F. DE ROUGEMONT, Doctor of Medicine (1967)

Mr. ROGER GALLOPIN, Doctor of Laws, former ICRC Director-General (1967)

Mr. WALDEMAR JUCKER, Doctor of Laws, Secretary, Union syndicale suisse (1967)

Mr. VICTOR H. UMBRICHT, Doctor of Laws, Managing Director (1970)

Mr. PIERRE MICHELI, Bachelor of Laws, former Ambassador (1971)

Mr. PIERRE BOISSIER, Bachelor of Laws, Director of Henry Dunant Institute, Geneva (1973)

Mr. GILBERT ETIENNE, Doctor of Laws, Professor at the Graduate Institute of International Studies, Geneva (1973)

Mr. ULRICH MIDDENDORP, Doctor of Medicine, head of surgical department of the Cantonal Hospital, Winterthur (1973)

Miss MARION ROTHENBACH, Master of Social Work (University of Michigan), Reader at the Ecole des Sciences sociales et politiques of the University of Lausanne (1973)

Honorary members : Mr. JACQUES CHENEVIERE, Honorary Vice-President ; Miss LUCIE ODIER, Honorary Vice-President ; Messrs. GUILLAUME BORDIER, CARL J. BURCKHARDT, PAUL CARRY, MrS. MARGUERITE GAUTIER-VAN BERCHEM, Messrs. SAMUEL A. GONARD, EDOUARD de HALLER, RODOLFO OLGIATI, PAUL RUEGGER, FRÉDÉRIC SIORDET, ALFREDO VANNOTTI, ADOLF VISCHER.

\section{EXECUTIVE BOARD}

Mr. ROGER GALLOPIN, President

Mr. VICTOR H. UMBRICHT, Vice-President

Mrs. DENISE BINDSCHEDLER-ROBERT

Dr. ULRICH MIDDENDORP

Mr. GOTTFRIED DE SMIT 


\section{INTERNATIONAL REVIEW OF THE RED CROSS}

NOVEMBER 1973 - No. 152

\section{INTERNATIONAL COMMITTEE OF THE RED CROSS} IN THE RED CROSS
WORLD

\section{MISCELLANEOUS}

BOOKS AND REVIEWS
J. H. Rombach : Cornelius van Bynkershoek .... A Publication of the International Committee of the Red Cross $\ldots \ldots \ldots \ldots \ldots \ldots \ldots \ldots \ldots$

Recognition of the Central African Red Cross Society (Circular No 493 to the Central Committees)

The International Committee's Action in the Mid-

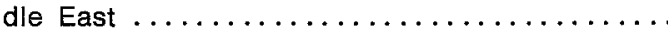

External Activities:

Chile - Asian sub-continent - Thailand ....... 589 In Geneva :

ICRC clarification $\ldots \ldots \ldots \ldots \ldots \ldots \ldots \ldots \ldots, 592$

School Textbook and Teachers Manual: The Red Cross and My Country - The Red Crescent and My Country ........................

International Red Cross Assistance in Indo-China 599

Regional Training Institute in West Africa ..... 602

Dissemination of the Geneva Conventions : Italy New Zealand ........................

Colloquium on Spiritual and Intellectual Assistance in Time of Armed Conflicts and Civil Disturbances ............................. 609

Health Education ..................... 612

Humanitarian Law Research .............. 615

Identification of Disaster Victims ........... 616 
FRENCH EDITION
OF THE REVIEW

SUPLEMENTS

TO THE REVIEW

\section{SPANISH}

GERMAN

INTERNATIONAL

REVIEW OF

THE RED CROSS
The French edition of this Review is issued every month under the title of Revue Internationale de la Croix-Rouge. It is, in principle, identical with the English edition and may be obtained under the same conditions.

Convocación de la Conferencia Diplomática - Reconocimiento de la Sociedad de la Cruz Roja Centroafricana (Circular núm. 493 a los Comités Centrales) La acción del Comité Internacional en Oriente Medio - Misión del CICR en Chile - Manual escolar y Libro del profesor : « La Cruz Roja y mi país * - * La Media Luna Roja y mi país».

Einberufung der Diplomatischen Konferenz - Die Aktion des Internationalen Komitees im Nahen Osten Schulhandbuch und Lehrerhandbuch: "La CroixRouge et mon pays $*$ - * Le Croissant-Rouge et mon pays " - Michael Bothe : "Das völkerrechtliche Verbot des Einsatzes chemischer und bakteriologischer Waffen ".

The International Review is published each month by the International Committee of the Red Cross

7, avenue de la Paix, CH - 1211 Geneva

Postal Cheque No. 121767

Annual subscription: Sw. Fr. 30.- $(\$ 8)$

Single coples Sw. Fr. 3.- $(\$ 0.80)$

Editor: J.-G. LOSSIER

The International Committee of the Red Cross assumes responsibility only for material over its own signature. 